\title{
Hercegowina na styku narodów, religii i języków
}

Krzysztof Krysieniel ${ }^{1}$

\begin{abstract}
:
Herzegovina at the crossroads of various nations, religions and languages. Herzegovina, although smaller in terms of area and population from Bosnia, has many features that distinguish it from the larger neighbour, with which it forms now a common state. Herzegovina has been mentioned earlier in the literature than Bosnia, it has a rich and often dramatic history. It is a typical frontier area where different nations, cultures and religions come to contact with each other. For centuries, Herzegovina has been strongly connected, mainly through commercial contacts, with the nearby Adriatic coast, and especially to Dubrovnik. It took over many of the customs and traditions of the Mediterranean, while being for a very long time under Turkish rule, and being inhabited by a large group of Orthodox Serbs. All these factors cause that despite the lack of commonly accepted boundaries, Herzegovina has its own characteristics, which distinguishes it from the neighbouring provinces. Unfortunately, this uniqueness is nowadays often denied due to political reasons, just like its name, which is often overlooked in the description of this very interesting region.
\end{abstract}

\section{Keywords:}

Herzegovina, Bosnia, national identity, the Yugoslav Wars, history of Herzegovina

\section{Streszczenie:}

Hercegowina, wprawdzie mniejsza pod względem powierzchni i liczby ludności od Bośni, posiada wiele cech odróżniajacych ją od większego sąsiada, z którym tworzy obecnie wspólne państwo. Wcześniej niż Bośnia wymieniana w literaturze, o bogatej i nierzadko dramatycznej historii, jest typowym obszarem pogranicza, gdzie stykaja się ze soba różne narody, kultury czy religie. Przez wieki silnie związana, głównie poprzez kontakty handlowe, z pobliskim wybrzeżem Adriatyku, a szczególnie z Dubrownikiem, przejęła wiele ze zwyczajów i tradycji śródziemnomorskich, będąc jednocześnie przez dlugi czas podporządkowana władcom tureckim, a do tego zamieszkana po części przez liczna grupe prawostawnych Serbów. Wszystkie te czynniki powoduja, $i \dot{z}$ - pomimo braku wytyczonych, powszechnie akceptowanych granic - Hercegowina posiada swoja specyfike, odróżniająca ją od sąsiednich prowincji. Niestety, jest ona wspótcześnie ze względów politycznych często negowana, podobnie zreszta jak sama nazwa, nieraz pomijana przy opisie tego jakże interesującego regionu.

\section{Słowa kluczowe:}

Hercegowina, Bośnia, tożsamość narodowa, wojna w Jugosławii, historia Hercegowiny

Link do artykułu:

http://pogranicze.uni.opole.p1/biblioteka/docs/nr1/krysieniel_nr1.pdt

Standard cytowania (APA):

Krysieniel, K. (2013). Hercegowina na styku narodów, religii, języków. Pogranicze. Polish Borderlands Studies, $n r$ 1, s. 83-90.

Niezwykle rzadko we współczesnym świecie występują państwa, w których nazwie znajduje się odwołanie do dwóch regionów (wysp, prowincji). Wśród nich można wymienić m.in. następujące: Antigua i Barbados, Saint Kitts i Nevis, czy też Trynidad i Tobago. Do 2006 roku można było wskazać jeszcze jeden przykład, znajdujący się w Europie - Serbię i Czarnogórę. We wszystkich tych przypadkach na pierwszym miejscu znajduje się jednostka większa pod względem terytorium. Takie podejście jest w pełni zrozumiałe i nie powinno budzić poważniejszych wątpliwości. Problemem jest natomiast to, czy i w jaki sposób mniejszemu podmiotowi udaje się uniknąć marginalizacji, zepchnięcia na plan dalszy przez dominującą jednostkę. $Z$ taką sytuacją mamy do czynienia w przypadku Bośni i Hercegowiny. Jest to

\footnotetext{
1 Dr hab. Krzysztof Krysieniel - politolog, prodziekan Wydziału Zamiejscowego w Chorzowie Wyższej Szkoły
} Bankowej w Poznaniu; członek Team Europe przy Przedstawicielstwie Komisji Europejskiej w Warszawie. 
kraj wielonarodowościowy, z trzema dominującymi religiami, o bogatej, ale często dramatycznej przeszłości, kojarzony jednak głównie z Bośnią, a w znacznie mniejszym stopniu z Hercegowiną ${ }^{1}$. Właśnie tej drugiej prowincji - historii, multietnicznej tradycji, ale i cechom charakterystycznym, pozwalającym odróżnić ją od Bośni, poświęcony jest niniejszy artykuł, którego celem jest znalezienie odpowiedzi na pytanie: czy Hercegowina stanowi corpus separatum w ramach jednego państwa, czy jest tylko amalgamatem, mieszaniną różnych cech, postaw i pojęć, nierzadko będących jedynie wyobrażeniem, a nie realnym bytem.

Między Bośnią a Hercegowiną nie zostały wytyczone granice pod względem prawno-administracyjnym, można mówić jedynie o granicach nieformalnych ${ }^{2}$. Granica jest pojęciem bardzo obszernym, powszechnie używanym w życiu codziennym, alei naukowym(Bański2010:489). Jak pisze Wojciech Muszyński, „granice mogą być rozpatrywane $\mathrm{w}$ aspekcie podmiotowym (poczucie, świadomość, akceptacja), przedmiotowym (występowanie), normatywnym (kryteria oceny wielkości) i deskryptywnym (faktyczne występowanie). W szczególnych przypadkach granice mogą też mieć charakter subiektywny (urojony) i nie muszą posiadać odzwierciedlenia w przesłankach obiektywnych" (Muszyński 2009: 7). Można zaryzykować stwierdzenie, że właśnie z taką sytuacją mamy do czynienia w przypadku Hercegowiny - krainy bez wyraźnych granic, leżącej na styku kilku kultur, religii i zamieszkiwanej współcześnie przez trzy narody.

Jak słusznie zauważa Radoslav Dodig, badacz chcący doprecyzować terytorium Hercegowiny stoi przez nie lada wyzwaniem, gdyż brak jest zgody co do tego, gdzie jej terytorium sięga. Jeszcze w czasach Socjalistycznej Federacyjnej Republiki Jugosławii, w zależności

$1 \quad$ Taka sytuacja ma miejsce również w polskich realiach - któż używa np. przymiotnika bośniackohercegowiński? Albo - w odniesieniu do mieszkańców regionu - określenia Hercegowińczyk?

2 W pewnym sensie podobne wnioski można odnieść w stosunku do granicy zachodniej i południowej (z Chorwacją) oraz wschodniej (z Czarnogórą). Zostały one wprawdzie wytyczone formalnie, ale $\mathrm{w}$ większości nie opierają się na np. wyraźnych przeszkodach geograficznych o charakterze naturalnym, a raczej są skutkiem decyzji politycznych sprzed wieków. od opracowania naukowego, obszar tej prowincji wahał się od $9426 \mathrm{~km}^{2}$ aż do $12276 \mathrm{~km}^{2}$ (w tym drugim przypadku granice Hercegowiny wytycza linia łącząca miasta: Trebinje, Livno, Šćit i Gacko). Upraszczając, można stwierdzić, że Hercegowina stanowi swego rodzaju geograficzne „zaplecze" dla chorwackiego wybrzeża od Splitu do Dubrownika. Jej powierzchnia stanowi - w zależności od podejścia - między jedną czwartą i jedną piątą całego obszaru państwa, a zamieszkuje ją co dziewiąty obywatel Bośni i Hercegowiny (Dodig 2006: 85-86).

\section{Geneza i ksztaltowanie się granic Humu/ Hercegowiny}

Przyglądając się losom ziem współczesnej Hercegowiny $\mathrm{z}$ pewnym zdziwieniem można stwierdzić, że w pisanych źródłach historycznych są one wymienione wcześniej niż Bośnia - fakt, że pod inną nazwą (Hum, Zahumlje - od nazwy jednej z gór). Ponadto trzeba zaznaczyć, że obszar Humu różnił się od tego, który dziś określa się mianem Hercegowiny, bowiem obejmował również fragment wybrzeża Adriatyku. Już w 925 roku w piśmie papieża Jana X wymieniony jest książę humski, Mihovil, który panował nad odrębnym bytem politycznym. Z kolei Bośnia po raz pierwszy została wymieniona $\mathrm{z}$ nazwy dopiero $\mathrm{w} 958$ roku w jednym $\mathrm{z}$ dokumentów wydanych przez cesarza bizantyjskiego Konstantyna VII Porfirogenita jako „Mała ziemia Bośnia” - horion Bosona (Čaušević 2005: 18; Malcolm 2002: 10). Podobnie rzecz się ma odnośnie władców obu ziem - pierwszy władca Bośni (ban Borić) został wymieniony $\mathrm{z}$ imienia $\mathrm{w}$ piśmie 225 lat po księciu humskim (Lučić 2006: 100).

Już w tamtych czasach był to obszar o zróżnicowanej strukturze etnicznej i religijnej. Mimo związków z kulturą łacińską i bliskości będącej pod wpływem Rzymu Dalmacji, w Hercegowinie (Humie) - inaczej niż w Bośni - ludność serbska przebywała już od XII wieku, od czasów dynastii Nemanjiciów (Goluža 1995: 105-106; Malcolm 2002: 10). Pewnym tego następstwem był znaczący odsetek ludności prawosławnej, która zamieszkiwała opisywany obszar. Tym samym na stosunkowo niewielkim terytorium współzamieszkiwali wyznawcy 
trzech religii: katolicyzmu, prawosławia oraz Kościoła bośniackiego, stanowiącego specyficzny i budzący do dziś kontrowersje odłam chrześcijaństwa (Imamović 2006: 35).

Pod zwierzchnictwo władców bośniackich Hum dostał się dopiero - i to na krótko - w 1326 roku. Silniejsze okazały się wpływy chorwacko-węgierskie. Kolejni książęta humscy prowadzili raczej samodzielną politykę, szczególnie panujący w połowie XV wieku Stefan Vukčić Kosača. Potwierdzeniem jego silnej pozycji było ogłoszenie pełnej niezależności prowincji (Lučić 2006: 101). Za jego rządów Hum obejmował obszar od świętego dla wyznawców prawosławia monastyru w Ostrogu (okolice dzisiejszego Nikšicia w Czarnogórze) na wschodzie, po miejscowość Imotski (w dzisiejszej Chorwacji) na zachodzie oraz od półwyspu Konavle na południu aż do okolic Ivanplanine na północy (Imamović 2006: 35).

Jak zauważa Joanna Rapacka, Stefanovi Vukčiciovi Kosačy tytuł wojewody już nie wystarczał, dlatego ogłosił się hercogiem św. Sawy (Monastyr Mileševa, gdzie spoczywały kości św. Sawy Nemanjicia, znajdował się wówczas w posiadaniu Kosačy), przyczyniając się tym samym do zmiany nazwy rządzonej przez siebie prowincji na Hercegowinę. Kosača okazał się przy tym przebiegłym i skutecznym wodzem, znacznie poszerzając granice posiadłości. Uczynił to jednak przy pomocy potęgi tureckiej, którą wspierał się m.in. w walkach z władcami bośniackimi. Nie zdawał sobie przy tym sprawy, że budując własną potęgę kosztem Bośni, jednocześnie stwarzał warunki do ekspansji tureckiej w tym regionie. Kosača zmienił front $\mathrm{w}$ kilka lat po upadku Bośni, w 1463 roku, gdy pod jego panowaniem ostały się tylko ziemie wokół miasta Novi (dzisiejsze Hercegnovi). Było już jednak za późno, aby uratować ostatni skrawek Hercegowiny - Turcy podbili go w 1482 roku (Rapacka 2002: 34-35).

Interesujące jest to, że mimo oficjalnej zmiany nazwy prowincji, do określenia Hum w późniejszym okresie jeszcze sporadycznie powracano. Miało to miejsce np. podczas II wojny światowej, w okresie istnienia faszystowskiego Niezależnego Państwa Chorwackiego (NDH), gdy władze tego quasi-państwa pragnęły wykreślić jakiekolwiek wzmianki o Bośni i Hercegowinie. Dlatego zaanektowany obszar podzieliły na siedem żup, a jedną z nich był właśnie Hum (Čaušević 2005: 372).

Wracając do XV-wiecznej historii tego obszaru należy podkreślić, że po opanowaniu go przez Osmanów, utrzymano przez pewien czas podział na Bośnię i Hercegowinę. Obok siebie istniały dwie jednostki administracyjne, zwane sandżakami - bośniacki i hercegowiński, które dopiero później, pod koniec XVI wieku, włączono do jeszcze większej struktury terytorialnej - ejaletu Bośni. W tym przypadku Hercegowina przestała być traktowana na równi ze swoim większym sąsiadem. Ostateczny kształt ejaletu został potwierdzony na mocy podpisanego w Karłowicach traktatu pokojowego w 1699 roku (Imamović 2006: 52-53 i 59). Na mocy tego porozumienia ejalet Bośni (a de facto obszar Hercegowiny) ponownie uzyskał dostęp do Adriatyku, gdyż Republika Dubrownicka nie chcąc sąsiadować bezpośrednio z Republiką Wenecką - oddała Turkom Neum (Ibrahimagić 1998: 16). Ten niewielki skrawek wybrzeża, zamieszkały obecnie niemal wyłącznie przez Chorwatów (w większości posiadających podwójne obywatelstwo: Bośni i Hercegowiny oraz Republiki Chorwacji), do dziś oddziela okolice Dubrownika od pozostałej części Chorwacji (i zarazem Unii Europejskiej), co stwarza szereg problemów (np. dostęp do Neumu ze strony pozostałego terytorium Hercegowiny jest bardzo utrudniony, gdyż prowadzi tam tylko jedna, wąska, mocno uszkodzona droga. Znacznie lepszy dojazd jest z terytorium chorwackiego, zarówno od strony delty Neretwy, jak i Dubrownika).

Za czasów panowania tureckiego w Bośni i Hercegowinie wprowadzono niezwykły, jak na ówczesne realia, system polityczno-społeczny oparty na kryterium konfesyjnym. Był to tzw. system milletów, który miał przełomowe znaczenie dla procesów kształtowania się tożsamości mieszkańców tych ziem. Model ten stanowił próbę utrzymywania ładu i porządku w państwie wielonarodowym poprzez rozdzielenie kwestii etnicznych, kulturowych i religijnych od politycznych. Zapewniał on „(...) relatywnie szeroką autonomię polityczno-religijną niemuzułmanom, jednocześnie gwarantując 
uprzywilejowaną pozycję, status poddanych pierwszej klasy wyznawcom islamu. (...) oznaczało to wytworzenie głębokich podziałów, bardzo poważnie utrudniających budowę tożsamości ponadreligijnej" (Balcer 2008: 28-29). System milletów i jego funkcjonowanie przez kilkaset lat przyczyniły się do homogenizacji wspólnot konfesyjnych i ugruntowania osobnych przepisów w zakresie obyczajów, prawa własności, sądownictwa, zawierania małżeństw i szkolnictwa. Takie podziały - choć nie miały charakteru absolutnego ${ }^{3}$ - doprowadziły do ukształtowania się na obszarze Bośni i Hercegowiny grup o odrębnym poczuciu tożsamości narodowej. Jak zauważa Mario Vukoja, gdy w XIX wieku w innych państwach europejskich zaczęła się kształtować idea narodowa, w Bośni i Hercegowinie nie było już szans na stworzenie jednego narodu, gdyż podziały między członkami poszczególnych milletów zarysowały się zbyt głęboko (Vukoja 2004: 120).

\section{Hercegowina w XIX wieku i latach późniejszych}

Przełomowe znaczenie dla historii Bośni i Hercegowiny miał 1878 rok. Wtedy to $\mathrm{w}$ trakcie Kongresu Berlińskiego zdecydowano, że - w wyniku osłabienia Turcji kontrolę nad prowincją przejmą Austro-Węgry (przy czysto formalnym zachowaniu zwierzchnictwa sułtana). Nie można pominąć przy tym faktu, że dopiero w tekście porozumienia zawartego na Kongresie Berlińskim po raz pierwszy oficjalnie użyto dwuczłonowej nazwy Bośnia i Hercegowina, i to w wersji niemieckojęzycznej - Bosnien und Herzegowina (Ančić 2006: 66). Ponadto, wtedy także ostatecznie potwierdzono wszystkie granice prowincji, które obowiązują także współcześnie (Imamović 2003: 319).

Druga połowa XIX wieku miała kluczowe znaczenie również dla ukształtowania się świadomości narodowej mieszkańców Bośni i Hercegowiny. Okupacyjne władze austro-węgierskie podjęły wprawdzie próbę

\footnotetext{
3 Wśród wyznawców katolicyzmu i prawosławia powszechne były pewne tradycje typowe dla islamu, natomiast muzułmanie kultywowali wiele zwyczajów chrześcijańskich. Utrzymywaniu kontaktów służyło wspólne słowiańskie pochodzenie oraz porozumiewanie się tym samym językiem.
}

utworzenia jednego, ponadreligijnego narodu, ale zakończyła się ona fiaskiem. Ludność prawosławna w coraz większym stopniu utożsamiała się z narodem serbskim, który w bezpośrednim sąsiedztwie (za rzeką Drina) wybił się na niepodległość i stworzył własne państwo, natomiast katolicy byli identyfikowani jako Chorwaci, czemu także sprzyjała bliskość geograficzna i wielowiekowe kontakty (szczególnie dotyczyło to Hercegowiny). Nawet muzułmanie (czyli mieszkający w Bośni i Hercegowinie Słowianie, którzy przyjęli islam) zaczęli podkreślać swoją odrębność od tureckich braci w wierze (Filipović 2009: 11).

Specyfiką opisywanego obszaru jest to, że mimo coraz wyraźniejszych pod koniec XIX wieku różnic narodowych, wszyscy mieszkańcy posługiwali się niemal identycznym językiem. Dla cudzoziemca różnice między mową używaną przez ludność muzułmańską, serbską i chorwacką były (i są nadal) niezwykle trudne do wychwycenia. Jak twierdzą językoznawcy, różnice leksykalne między językiem bośniackim, chorwackim i serbskim wynoszą od 3 do 7 proc., czyli przeciętnie 95 proc. jest wspólne (Sotirović 2009). Z punktu widzenia niniejszych rozważań istotne jest to, że dialekt sztokawski ${ }^{4}$, który w pierwszej połowie XIX wieku był podstawą dla Serba Vuka Karadžicia i Chorwata Ljudevita Gaja do opracowania standardowych języków literackich dla swoich narodów, pochodzi ze wschodniej Hercegowiny.

Po przejęciu kontroli przez Austro-Węgry nad Bośnią i Hercegowiną (wzmocnionej po pełnej aneksji w 1908 roku), losy obu prowincji kształtowały się bardzo podobnie. Tak samo coraz wyraźniejszy był proces przekształcania się wspólnot religijnych w narodowe. Ze względu na strukturę etniczną, Hercegowina stawała się - oprócz środkowej Bośni głównym centrum kształtowania się wspólnoty chorwackiej, wzmocnionej dodatkowo przez ożywione kontakty z sąsiednią Dalmacją.

Gdy wybuchła I wojna światowa, Bośnia i Hercegowina stała się bezpośrednim zapleczem dla frontu - ze wszystkimi tego negatywnymi cechami. Ponadto sympatie jej mieszkańców rozkładały się $\mathrm{w}$ zależności od

\begin{tabular}{l}
\hline 4 Oprócz dialektu sztokawskiego, można \\
wyróżnić czakawski, kajkawski i torlacki.
\end{tabular} 
przynależności etnicznej (np. serbscy ochotnicy $\mathrm{z}$ Hercegowiny $\mathrm{w}$ liczbie trzech batalionów dołączyli do wojsk Czarnogóry, podczas gdy muzułmanie, a przede wszystkim Chorwaci wspierali armię austro-węgierską). Po zakończeniu działań zbrojnych powstało Królestwo Serbów, Chorwatów i Słoweńców, później przemianowane na Królestwo Jugosławii. Mimo silnych tendencji centralistycznych i dążenia władz w Belgradzie do zatarcia wielowiekowych podziałów wewnętrznych, Bośnia i Hercegowina jako jedyna prowincja uzyskała konstytucyjne gwarancje zachowania granic, a także utrzymania niektórych spośród dotychczasowych praw, m.in. sądów szariackich dla muzułmanów (Čaušević 2005: 281).

Taka sytuacja utrzymała się do 1929 roku. Wówczas król Aleksander dokonał zamachu stanu i zawiesił obowiązywanie konstytucji. Następnie narzucił nowe przepisy dotyczące podziału terytorialnego, ignorując przy tym odmienność historyczną, kulturową i etniczną poszczególnych regionów. Dotyczyło to także obszaru Bośni i Hercegowiny, który został podzielony na cztery banowiny. Takie decyzje spowodowały, że ,(...) po raz pierwszy w tysiącletniej historii Bośnia i Hercegowina całkowicie zniknęła z mapy Europy"(Hoare 2007: 116-117).

Królestwo Jugosławii przestało istnieć w wyniku agresji wojsk hitlerowskich i ich sojuszników w kwietniu 1941 roku. Sama Bośnia i Hercegowina, formalnie włączona do faszystowskiego państewka NDH, stała się areną niezwykle krwawych walk, toczonych właściwie między wszystkimi aktorami konfliktu, a także centrum najważniejszych wydarzeń o charakterze politycznym. Warto zwrócić uwagę, że doszło wówczas do podziału - Bośnia znalazła się w niemieckiej strefie okupacyjnej, natomiast Hercegowina we włoskiej. Od samego też początku stała się polem konfliktu międzyetnicznego - dominujący liczebnie Chorwaci w większości opowiedzieli się za nowym państwem, Serbowie ze wschodniej Hercegowiny odmówili uznania (i często tworzyli oddziały partyzanckie różnej proweniencji), a część muzułmańskiej elity domagała się autonomii. (Lučić 2006: 104).

W Bośni i Hercegowinie przez większość wojny stacjonowały oddziały partyzantki komunistycznej Josipa Broz-Tity oraz kształtowały się zręby władzy, która po wojnie przejęła kontrolę nad całym terytorium Jugosławii. Pod koniec działań zbrojnych chorwackie elity z Hercegowiny zostały dotknięte masowymi prześladowaniami ze strony wojsk komunistycznych, co stanowiło formę zemsty za poparcie NDH.

W nowym, socjalistycznym państwie Bośnia i Hercegowina stała się jedną z republik związkowych. Jedyną, w której nie można było wskazać narodu dominującego, ale trzy formalnie równorzędne - Serbów, Chorwatów i Muzułmanów (pisanych dużą literą od 1961 roku). W oficjalnej propagandzie dominowała idea „braterstwa i jedności”, dlatego wszelkie przejawy niezadowolenia ze strony przedstawicieli każdego z narodów były thumione w zarodku. Twarda postawa komunistycznych władz doprowadziła do względnego spokoju społecznego i wyciszenia, przejściowego, jak się miało okazać, konfliktów etnicznych.

\section{Hercegowina w czasach wspólczesnych}

Rozpad Jugosławii na początku lat 90. XX wieku wywołał najtragiczniejszy konflikt zbrojny w Europie po II wojnie światowej. Szczególnie dramatyczny okazał się on w wieloetnicznej Bośni i Hercegowinie, gdzie w latach 1992-1995 w wyniku walk zginęło ok.100 tysięcy osób ${ }^{5}$. Na większości obszaru Hercegowiny walki miały przede wszystkim charakter konfliktu między Chorwatami i Muzułmanami (od 1993 roku oficjalnie określanymi Bośniakami ${ }^{6}$ ), choć wschodnia część regionu (a na początku 1992 roku także centralna $\mathrm{z}$ Mostarem) leżała w rękach wojsk serbskich. Ciężkie walki w Hercegowinie zakończyły się de facto wiosną 1994 roku, gdy zawarto porozumienie między samozwańczymi władzami chorwackimi a zdominowanym przez Bośniaków rządem w Sarajewie. Ostatecznie wojna w Bośni i Hercegowinie zakończyła

\footnotetext{
$5 \quad$ Dane za: Haag utvrdio broj žrtava rata $u$ BiH, www.dnevnik.ba z dnia 20.05.2010.

6 Bošnjaci. W języku polskim nie przyjęła się próba wprowadzenie etnonimu „Boszniak”, dlatego przeważnie używa się wobec byłych Muzułmanów określenia „Bośniak” - co jednak może wprowadzać w błąd.
} 
się jesienią 1995 roku, parafowaniem porozumienia pokojowego w Dayton (Krysieniel 2012: 215-234).

Narzucone Bośni i Hercegowinie po Dayton wewnętrzne podziały polityczno-administracyjne w żaden sposób nie odwzorowują granic historycznych, geograficznych czy gospodarczych. Utworzono dwie jednostki o szerokim zakresie autonomii - Federację Bośni i Hercegowiny (podzielono ją na 10 kantonów, z czego trzy znajdują w Hercegowinie) oraz Republikę Serbską, a granice między nimi stanowią niemal dokładne odwzorowanie linii frontu z listopada 1995 roku. W wyniku tego Hercegowina podzielona została na mniejszą część wschodnią, gdzie mieszkają Serbowie (z największym miastem Trebinje), oraz większą, zachodnią, $z$ dominacją ludności chorwackiej i bośniackiej (z Mostarem jako największym miastem, ale podzielonym na część chorwacką i bośniacką). Głębokie podziały etniczne stały się chyba najbardziej charakterystycznym wyróżnikiem tego regionu.

Jak pisze Mirko Pejanović, gdyby uwzględnić czynniki racjonalne, w Bośni i Hercegowinie powinny zostać wyodrębnione cztery regiony ze stolicami w Banja Luce, Sarajewie, Tuzli i Mostarze. Ten ostatni obejmowałby obszar Hercegowiny, opierając się na wykształconych przez wieki powiązaniach ekonomicznych, geograficznych, kulturowych i społecznych (Pejanović 2007: 69). Za krok - choć z perspektywy lat trzeba uznać, że o niewielkim znaczeniu - w stronę racjonalnego podziału administracyjnego państwa można uznać działalność (od 2001 roku) regionalnych agencji rozwoju, finansowanych m.in. przez Komisję Europejską i Bank Światowy. We wspomnianym projekcie za najbardziej efektywny dla rozwoju gospodarczego uznano podział państwa na pięć makroregionów z siedzibami w Sarajewie, Banja Luce, Tuzli, Zenicy oraz Mostarze. Ten ostatni (,Makroregion ekonomiczny Hercegowina") obejmuje 27 gmin, z czego 21 znajduje się w Federacji Bośni i Hercegowiny, a sześć w Republice Serbskiej (Sadiković 2006: 152).

Oprócz granic polityczno-administracyjnych ukształtowały się w Hercegowinie (jak i w Bośni) głębokie podziały kulturowe, częstojednakże wytyczane na siłę. Bezwątpienia można wskazać w tym miejscu przykład języka. W latach 90. XX wieku Serbowie wykazali przywiązanie do cyrylicy, której praktycznie na tym obszarze nie używano od czasów II wojny światowej. Do tego zaczęli używać wariantu ekawskiego, stosowanego w Serbii. Chorwaci z kolei starają się nawiązywać do "czystego" chorwackiego, opartego na wariancie jekawskim. Nasiliła się również wśród nich presja na tworzenie nowych wyrazów - aby tylko odróżnić się od języka serbskiego. Takie postępowanie stwarza przestrzeń dla nowego języka: bośniackiego, używanego przez Bośniaków, czyli dawnych Muzułmanów (Szul 2009: 329). Zawiera on konstrukcje składniowe $\mathrm{z}$ obu wariantów jednocześnie, wzajemnie się przenikające i mieszające. Upraszczając - pod względem gramatyki i wymowy bośniacki bliższy jest językowi chorwackiemu, a pod względem słownictwa - serbskiemu.

Podobne granice o raczej nieformalnym charakterze pojawiły się po wojnie w przypadku kwestii wyznaniowej. O ile za czasów Socjalistycznej Federacyjnej Republiki Jugosławii różnice konfesyjne miały marginalne znaczenie (normą było np. wspólne obchodzenie świąt przez wyznawców różnych religii), to już $\mathrm{w}$ trakcie konfliktu wiara, a właściwie jej symbole, zaczęła odgrywać kluczowe znaczenie. W całym państwie, w tym także na obszarze Hercegowiny, doszło do przeprowadzonych w sposób masowy i zaplanowany zniszczeń „nieprawomyślnych” świątyń. Po wojnie blokowano odbudowę tych zniszczonych miejsc kultu, które nie należały do dominującego na danym obszarze - w następstwie czystek etnicznych - narodu. Doskonałym przykładem rywalizacji wspólnot religijnych jest sytuacja w największym mieście Hercegowiny, Mostarze, oraz w jego okolicach. Ma tam miejsce swoisty „wyścig wysokościowy" między meczetami i kościołami, a jego symbolem jest katolicki krzyż na wznoszącej się nad miastem górze Hum. Jest on słabo dostrzegalny ze strony dzielnic zamieszkanych przez Chorwatów, ale za to doskonale widoczny z części muzułmańskiej (Babić 2008). 


\section{Zakończenie}

Słusznie zauważa Joanna Kurczewska, że „(...) zjawisku otwierania się granic politycznych towarzyszy odradzanie się etniczności i regionalizmów, co prowadzi do ponownego definiowania i wzmacniania granic kulturowych. (...) linie demarkacyjne tworzy rasa, język, religia, patriotyzm regionalny czy bagaż doświadczeń historycznych" (Kurczewska 2005: 18). Jednocześnie na tak skomplikowanym pod względem etnicznym obszarze, jakim są Bałkany Zachodnie, obraz granic terytorium etnicznego jest niezwykle mętny. Przestrzeń życiowa nie pokrywa się z obszarem zamkniętym granicami państwowymi, oficjalnymi, przekracza nawet takie naturalne bariery, jakimi są góry czy rzeki (Čolović 2001: 41).

Wielu mieszkańców tego regionu zapewne mogłoby się podpisać pod następującą wypowiedzią pewnego dziennikarza $\mathrm{z}$ dziennika „Vjesnik”: „Hercegowińczyk (oryg. Hercegovac - przyp. K.K) oznacza dzisiaj znacznie więcej niż tylko termin geograficzny. To w kolektywnym odczuciu bardziej jednostka obdarzona pewnymi określonymi cechami, a nie tylko przynależność terytorialna" (Dodig 2006: 86). Patrząc z perspektywy historycznej, nie jest to osąd bezpodstawny. Hercegowina przez długi czas zachowywała jedność terytorialną - jako księstwo, sandżak, okręg; czasami nawet wybijała się na niezależność. Była częścią różnych królestw i imperiów - chorwackiego, węgierskiego, serbskiego, bośniackiego, tureckiego, austro-węgierskiego, NDH i dwóch Jugosławii. Choć obecnie często pomijana (nawet $\mathrm{w}$ oficjalnym nazewnictwie ${ }^{7}$ ), stojąca w cieniu silniejszego partnera - Bośni, po czystkach etnicznych i przedzielona linią rozgraniczającą dwie jednostki - Federację i Republikę, odróżnia się jako region swoją wielowiekową historią, tradycją i silnymi związkami z Dalmacją. Jak pisze Božo Žepić: „Hercegowina, jej mieszkańcy i narody, i jej bogata kulturowo-historyczna spuścizna nie mogą zaniknąć, ponieważ stoi za nimi wysoki poziom rozwoju cywilizacyjnego" (Žepić 2006: 149).

Odpowiadając na pytanie postawione we wstępie można stwierdzić, że wprawdzie Hercegowina stanowi po części pewne wyobrażenie jej mieszkańców, to jednak bez wątpienia ma tyle specyficznych cech, iż należy traktować ją jako odrębny, realny byt, stanowiący wraz z Bośnią jedno państwo. Warto mieć więc na uwadze, że kraj ze stolicą w Sarajewie to nie tylko powszechnie znana i kojarzona Bośnia, ale, choć mniejsza i czasami pomijana, także i Hercegowina.

\begin{tabular}{l}
\hline $7 \quad$ Przykładem takiego postępowania niech \\
będzie następująca sytuacja: w 2005 roku ambasador \\
Bośni i Hercegowiny przy NATO, Sven Alkalaj, na \\
dokumentach jako oficjalną nazwę swojej placówki \\
w języku francuskim przyjął Ambasade de Bosnie, \\
całkowicie ignorując człon „Hercegowina”.
\end{tabular}

$7 \quad$ Przykładem takiego postępowania niech iztepująca sytuacja: w 2005 roku ambasado dokumentach jako oficjalna nazwę swojej placówki w języku francuskim przyjął Ambasade de Bosnie,

\section{Literatura:}

Ančić, M. (2006). Što je Bosna bez Hercegovine. Status, $n r 8$.

Babić, D (2008) Bošnjački raskoli Nova srpska politička misan Pohrano $16112013, \mathrm{z} \cdot \mathrm{http} / / \mathrm{h}$ www.nspm.rs/sudbina-dejtonske-bih-i-republika-srpska/bosnjacki-raskoli.html?alphabet=1

Balcer, A. (2008). Zarys rozwoju bośniackiej tożsamości narodowej w Bośni. W: P. Żurek (red.), Tantum Historiae. Księga ofiarowana profesorowi Mieczysławowi Tantemu w osiemdziesiąta rocznice urodzin. Bielsko-Biała.

Bański, J. (2010). Granica w badaniach geograficznych - definicja i próby klasyfikacji. Przegląd Geograficzny, nr 4.

Čaušević, D. (2005). Pravno politički razvitak Bosne i Hercegovine. Dokumenti sa komentarima. Sarajevo: Magistrat.

Čolović, I. (2001). Polityka symboli. Eseje o antropologii politycznej. Kraków: Univeritas.

Dodig, R. (2006). Hercegovina ili edej o ,zemlji na ćenaru”. Status, $n r 8$.

Filipović, M. (2009). Ko smo mi Bošnjaci? Duh Bosne, nr 2.

Goluža, B. (1995). Katolička crkva u Bosni i Hercegovini 1918.-1941. Mostar: Teološki institut. Hoare, M.A. (2007). The History of Bosnia. From the Middle Ages to the Present Day. London: Saqi Books. 
Ibrahimagić, O. (1998). Državno-pravni razvitak Bosne i Hercegovine. Sarajevo: Biblioteka Posebna Izdanja.

Imamović, M. (2003). Bošnjački etnos: identitet i ime. Prilozi, nr 32.

Imamović, M. (2006). Osnove upravno-političkog razvitka i državnopravnog položaja Bosne i Hercegovine. Sarajevo: Pravni fakultet Univerziteta u Sarajevu.

Krysieniel, K. (2012). W cieniu Dayton. Bośnia i Hercegowina między etnokracją a demokracja konsocjonalna. Warszawa: Wydawnictwo Sejmowe.

Kurczewska, J. (2005). Granice III RP jako problem badawczy. W: M. Malikowski, D. Wojakowski (red.), Granice i pogranicza nowej Unii Europejskiej. Z badań regionalnych, etnicznych i lokalnych. Kraków: Zakład Wydawniczy Nomos.

Lučić, I. (2006). Ima li Hercegovine? Status, $n r 8$.

Malcolm, N. (2002). Bosnia. A Short History. London: Pan Books.

Muszyński, W. (2009). Wieloznaczność granic w doświadczeniu jednostkowym i społecznym w epoce globalizacji. W: W. Muszyński, E. Sikora (red.), „Pod wielkim dachem nieba”. Granice, migracje i przestrzeń we współczesnym społeczeństwie. Toruń: Wydawnictwo Adam Marszałek.

Pejanović, M. (2007). Istorijsko oblikovanje regija i mogućnosti upostave regionalne strukture Bosne i Hercegovine u postdejtonskom periodu. Godišnjak Fakulteta političkih nauka, nr 2.

Rapacka, J. (2002). Śródziemnomorze - Europa Środkowa - Bałkany. Studia z literatur potudniowosłowiańskich. Kraków: Universitas.

Sadiković, E. (2006). Regionalizacija Bosne i Hercegovine kao predpostavka integracije u Evropsku uniju. Godišnjak Fakulteta političkih nauka, nr 1.

Sotirović, V.B. (2009). Bosanskijezik,Bošnjaci i Bosna i Hercegovina Nova srpska političkg

misao Pohrano $15112013, z \cdot$ http./www nspm rs/sudbina-dejtonske-bih-i-republika-srpska

bosanski-jezik-bosnjaci-i-bosna-i-hercegovina.htm

Szul, R. (2009). Język - naród - państwo. Język jako zjawisko polityczne. Warszawa: Wydawnictwo Naukowe PWN.

Vukoja, M. (2004). U potrazi za identitetom. Status, $n r 4$.

Žepić, B. (2006). Hercegovina između negiranja i opstanka. Status, $n r 8$. 